\title{
PANDEMIE PŘIPRAVILA ŠKOLSTVÍ ZAJÍMAVÉ VÝZVY, SHODLI SE ODBORNÍCI NA VZDĚLÁVACÍ KONFERENCI V LITVÍNOVĚ
}

\section{Radmila Čukatová}

ORLEN Unipetrol, Litvínov - Záluži

Radmila.Cukatova@orlenunipetrol.cz

\begin{abstract}
Druhý ročník konference 4EDU přinesl téma inovativní formy vzdělávání a př́ležitosti výuky v kyberprostoru. Událost přilákala stovku účastníků včetně pedagogů, ředitelů škol, zástupců zřizovatelů škol a studentů; dalších trri sta diváků ji zhlédlo online. Konferenci uspořádala Nadace ORLEN Unipetrol a Gymnázium Josefa Jungmanna v Litoměřicích pod záštitou města Litvínov. Přednášející sdíleli př́klady aktivit nad rámec výuky či ukázky praxe v soukromém sektoru. Odborníci také otevřeli téma hrozeb $\mathrm{v}$ kyberprostoru a představili široké možnosti využití streamování pro výuku chemie na YouTube. Konference 4EDU se konala v Tréninkovém centru společnosti ORLEN Unipetrol v Litvínově a nabídla přednášky zástupců základních a středních škol, VŠCHT v Praze, Akademie věd, Policie ČR a skupiny ORLEN Unipetrol.
\end{abstract}

\section{UNIVERZITNÍ CENTRUM VŠCHT - FS ČVUT - ORLEN UNIPETROL}

\section{ToMáš Herink}

\section{ORLEN Unipetrol, Litvínov - Záluži Tomas.Herink@unipetrol.cz}

V roce 2002 zahájila rafinérsko-petrochemická skupina ORLEN Unipetrol partnerskou spolupráci s Vysokou školou chemicko-technologickou v Praze (VŠCHT), která $\mathrm{v}$ roce 2015 vyvrcholila založením společného Univerzitního centra. Centrum se nachází př́mo ve výrobním areálu ORLEN Unipetrolu v Záluží u Litvínova a propojuje model výuky na veřejné vysoké škole s realizací dlouhodobé praxe. Díky specifickému prostředí chemické výroby získávají studenti možnost ověřit si nabyté teoretické znalosti rovnou v praxi, a to po celou dobu pětiletého studia. $\mathrm{Na}$ třech bakalářských a jednom navazujícím programu zde studuje až 50 vysokoškoláků, kteří mají možnost zapojit se do celé řady výzkumně vzdělávacích aktivit, které Univerzitní centrum nabízí či organizuje a $\mathrm{v}$ rámci kterých si mohou studenti realizovat své kvalifikační práce na některém $\mathrm{z}$ mnoha nabízených průmyslových témat. Po nástupu do Univerzitního centra mohou studenti získat stipendium Nadace ORLEN Unipetrol nebo se zapojit jako pomocná vědecká síla do projektů souvisejících s výzkumem, optimalizací výrob nebo vzděláváním a popularizací chemie zaměřené na střední a základní školy. Na konci roku 2020 se dalším partnerem Univerzitního centra stala Fakulta strojní ČVUT v Praze, která v prvních fázi přenáší část své laboratorní výuky do litvínovského areálu.

Jak Univerzitní centrum vypadá? Nejsou to pouze učebny, ale i laboratoře a výzkumné pilotní jednotky společnosti ORLEN UniCRE. Od roku 2020 je zcela nedílnou součástí také Tréninkové centrum, které ORLEN Unipetrol zrealizoval v budově bývalé výzkumné základny. Účelem Tréninkového centra je zajistit praktické zázemí pro výcvik nových operátorů, zázemí pro výzkumné a vývojové aktivity a poskytovat trvalé zázemí pro vzdělávání a výcvik v oblasti bezpečnosti práce a požární ochrany. Infrastruktura Tréninkového centra je využívána jak interními, tak i externími subjekty, přičemž klíčovou externí cílovou skupinou jsou vysoké a střední školy, které mohou využivat Tréninkové centrum pro zajištění odborných praxí a výuku či realizaci diplomových a doktorských prací. V neposlední řadě, $v$ rámci aktivit popularizace výuky chemie, je Tréninkové centrum využiváno pro základní školy v rámci tzv. „Zážitkových dní“. V současné době je Tréninkové centrum vybaveno těmito jednotkami:

- Kontinuální dálkově řízená destilační jednotka (tandem atmosférická a vakuová) $\mathrm{s}$ kapacitou nástřiku až $10 \mathrm{~kg}$ uhlovodíků za hodinu. Tandem kolon zapojených v sérii umožňuje výzkum a zároveň výcvik a výuku fyzikálně-chemických zákonitostí destilace (regulace teploty, průtoku, kvality nástřiku, hladiny, refluxu a tlaku) a rovněž seznámení s klíčovými aparáty či zařízením (čerpadla, vývěvy, regulační ventily, pojistné ventily, ručně ovládané armatury, nádoby, potrubí, prírubové spoje, prvky měření a regulace, izolace apod.). Jednotka je vhodná pro vysokoškolské a středoškolské praxe, praktickou výuku chemického inženýrství nebo realizace semestrálních projektů či bakalářských prací. Ve specifických př́ipadech je jednotka vhodná pro výzkumné aktivity, a tedy i pro účely doktorských prací. Na jednotce probíhá pravidelný výcvik nových operátorů.

- Cvičná, dálkově řízená jednotka na sdílení tepla s regulací teploty, průtoku a hladiny. Jednotka umožňuje výcvik a výuku principů sdílení tepla a zároveň seznámení s klíčovými aparáty či zařízením (výměníky, strojní chlazení, čerpadla, regulační ventily, ručně ovládané armatury, nádoby, potrubí, př́írubové spoje, prvky měření a regulace, izolace). Na jednotce je realizován trénink $\mathrm{s}$ akcentem na najíždění, odstavení a řízení jednotky s bezpečnými médii, párou a vodou. Jednotka je vhodná pro zajištění vysokoškolských a středoškolských praxí, praktickou výuku chemického inženýrství nebo realizace semestrálních projektů. Na jednotce probíhá pravidelný výcvik nových operátorů.

- Dvě počítačem řízené paralelní univerzální jednotky 
(experimentální a referenční) zaměřené na výzkum procesů čištění odpadních vod. Nátok 30 litrů denně reálné odpadní vody na jednu linku s použitím chemikálií shodných s chemikáliemi biologické čistírny Litvínov. Jednotky jsou osazeny 16 ks on-line analyzátorů. Jednotka byla vyvinuta ve spolupráci s Ústavem technologie vody a prostředí VŠCHT Praha. Jednotka je vhodná pro zajištění vysokoškolských praxí, výzkum a realizace diplomových či doktorských prací.

- Počítačem řízená vsádková jednotka na předúpravu použitého kuchyňského oleje (UCO) pro účely dalšího zpracování na pokročilá biopaliva. Jednotka umožňuje zpracovávat až $600 \mathrm{~kg}$ UCO za den. Základem jednotky je filtrace, odstředění a sušení použitého kuchyňského oleje. Jednotka je vhodná pro zajištění vysokoškolských a středoškolských praxí, praktickou výuku chemického inženýrství či realizace semestrálních projektů. V současné době je jednotka plně využivána pro př́ípravu UCO na další zpracování v reálných podmínkách rafinérie na hydrogenaci plynového oleje.

- Počítačem ř́zená testovací pyrolýzní jednotka na zpracování odpadních plastů a pneumatik s kapacitou $15 \mathrm{~kg}$ za hodinu. Jednotka je instalována pro účely výzkumu chemické recyklace plastů a pneumatik. Jednotka umožňuje zpracovávat různé druhy odpadních plastů a pneumatik při různých provozních podmínkách a sledovat vliv na množství a kvalitu produktů, především tzv. pyrolýzních kondenzátů. Jednotka je vhodná pro zajištění vysokoškolských a středoškolských praxí, výzkum a pro realizaci diplomových či doktorských prací.

- Výcvikový areál pro požárně bezpečnostní trénink s praktickými stanovišti hašení uhlovodíků v záchytné jímce, hašení motorů a čerpadel, hašení rozvaděčů a zdolávání tzv. „Jet Fire“ odkláněním plamene od zařízení. Areál dále poskytuje simulace úniku kapalin $\mathrm{z}$ netěsných armatur, simulace úniku kapalin z praskliny $\mathrm{v}$ zásobníku, simulace úniku plynu $\mathrm{z}$ armatury, ukázky skladby izolací na nádobách včetně hašení pod izolacemi, ukázky vodní a parní clony, sprinkler a plynové a plamenové detekce. Areál je vhodný pro zajištění vysokoškolských a středoškolských praxí, pro praktickou výuku předmětu Bezpečnost chemických výrob, Toxikologie či realizaci semestrálních projektů.

- Samostatná univerzální laboratoř pro praktický výcvik i stanovení vlastností produktů provozujících jednotek. V laboratoři je instalován např́íklad plynový chromatograf s automatickým dávkováním vzorků, kolorimetr, digitální pH metr, konduktometr, digitální hustoměr, spektrofotometr a automatický destilační systém na stanovení destilační křivky. Technologická laboratoř je vhodná pro zajištění vysokoškolských a středoškolských praxí a realizace semestrálních, diplomových či doktorských prací.

Univerzitní centrum představuje studijní a poté i kariérní př́ležitost, která prostřednictvím poněkud méně konvenčního technického vzdělávání a propojování teorie s praxí v rámci Ústeckého kraje přispívá $\mathrm{k}$ budování atraktivity a konkurenceschopnosti nejen oboru průmyslové chemie, ale i tohoto kraje obecně. Studenti kvůli studiu nemusí opouštět svi̊j kraj a tím se zvyšuje i šance, že v něm i po ukončení studia setrvají. Ukazuje se, že takto nastavené propojení mezi akademickou a průmyslovou sférou je funkční a přináší konkrétní pozitivní výsledky. $\mathrm{Za}$ šest let fungování Univerzitního centra lze např́iklad z rostoucího počtu přihlášek z Ústeckého kraje na VŠCHT Praha vysledovat rostoucí trend $\mathrm{v}$ rámci celorepublikového srovnání. Univerzitní centrum v tomto ohledu sehrává významnou roli, jelikož právě s jeho vybudováním začaly počty přihlášek ze škol Ústeckého kraje trvale stoupat. S ohledem na potenciál Univerzitního centra je připravován na VŠCHT Praha záměr rozšíriit studijní nabídku Univerzitního centra o nový studijní obor s názvem „Inženýr průmyslových a technologických materiálů“. Studijní program by měl být príležitostí zejména pro studenty a firmy s technickým a chemickým zaměřením nejen v Ústeckém kraji, ale i v sousedních krajích.

\section{CHEMICKÁ OLYMPIÁDA - POUHÁ PŘEDMĚTOVÁ SOUTĚŽ?}

\section{Petr Holzhauser}

Ústav učitelství a humanitních věd, Vysoká škola chemickotechnologická v Praze, Praha petr.holzhauser@vscht.cz

\section{Úvod}

Chemická olympiáda $(\mathrm{ChO})$ je předmětová soutěž s téměř šedesátiletou tradicí. Organizační řád ChO (cit. ${ }^{1}$ ) vymezuje povahu a cíl soutěže: „Jejím cílem je vyhledávat, rozvijet a podporovat talent a nadáni žákio základnich a střednich škol a zároveň nabídnout žákům ... účelné využití části jejich volného času. " Je tedy možné identifikovat tři hlavní cíle, role, nebo funkce této soutěže: výběrovou, motivační a vzdělávací.

Na základě osobní zkušenosti a dlouhodobého kontaktu s účastníky ChO můžeme identifikovat ještě čtvrtou, naprosto zásadní funkci soutěže, jež souvisí se současným fungováním komunity kolem ChO a s výsledky a úspěchy, kterých její členové dosahují, a to je funkce sociální. Tato funkce je spjata zejména s pořádáním Národních kol a zejména pak s fenoménem letních odborných soustředění $v$ Běstvině.

\section{Národní kola ChO}

Nejvyšším postupovým kolem kategorií A a E ChO je Národní (ústřední) kolo ${ }^{1}$. Národní kola jsou tradičně pořádána na konci ledna ve spolupráci s některou $\mathrm{z}$ univerzit, která disponuje dostatečnou kapacitou chemických laboratoř́i. Tato tradice byla $\mathrm{v}$ novodobé historii porušena pouze dvakrát: v roce 2017 se Národní kolo konalo ve spolupráci 
se společností Unipetrol a.s. v Litvínově $\mathrm{v}$ laboratořích UniCRE a v roce 2021 proběhlo $\mathrm{z}$ důvodu pandemie online bez praktické části. Nadcházející 58. Národní kolo proběhne v lednu 2022 historicky poprvé v Plzni na půdě Fakulty pedagogické Západočeské univerzity.

Klíčové pro naplnění sociální funkce ChO je fakt, že organizátoři tato kola pořádají nikoliv jako pouhou soutěž, ale jako společenské setkání účastníků, autorů a recenzentů úloh a často i učitelů, kteří svoje žáky na soutěž připravují. Kromě teoretického a praktického soutěžního bloku je vždy připraven i bohatý program v podobě exkurzí, výletů a kulturních aktivit. Setkávání účastníků v neformální atmosféré tak vede k budování a udržování komunity $\mathrm{ChO}$.

\section{Letní odborná soustř̌edění v Běstvině}

Tradice odborných soustředění účastníků krajských kol stř̌edoškolských kategorií Chemické a Biologické olympiády pořádaných na letní táborové základně v Běstvině sahá do 90 . let minulého století. Jedná se o mimořádně populární akce, které mají vzdělávací a sociální funkci a motivují účastníky ke studiu př́rodovědných oborů.

U prŕležitosti 50. výročí ChO v roce 2014 vzniklo sesterské soustředění Běstvinka pro soutěžící ze základních škol. I toto soustředění se mezi účastníky stalo populární, vznikla tak nová tradice a v létě 2022 proběhne již devátý ročník této akce.

Pro atmosféru soustředění Běstvina a Běstvinka hraje významnou roli prostředí samotné táborové základny v Běstvině. Je unikátní svojí polohou a dopravní dostupností v rámci České republiky, kapacitou (120 žáků +40 lektorů) i krásnou př́rodou $\mathrm{v}$ podhưř́ Železných hor a možnostmi sportovního vyžití. V roce 2018 základnu od MŠMT ČR odkoupila VŠCHT Praha s př́slibem zachování tradičních vzdělávacích akcí a postupné rekonstrukce celého areálu. V plánu je vybudování výukové laboratoře s kapacitou 16 identických pracovních míst a ubytovny pro 40 osob, kde budou k dispozici i dvě menší učebny. Laboratoř vybavená digestořemi, rozvody médií a základními prrístroji umožní do budoucna pořádat školy $\mathrm{v}$ prírodě základních a středních škol, které nemají k dispozici vlastní laboratoře chemie, ale chtějí chemii prakticky vyučovat. Polovina třídy bude pracovat $\mathrm{v}$ laboratoři pod dohledem lektorů, druhá polovina může mít výuku v učebnách, účastnit se tematických prrírodovědných exkurzí do okolí nebo se věnovat sportovnímu vyžití. Celoroční provoz obou budov umožní akce pořádat i mimo hlavní letní sezónu, tedy v průběhu celého školního roku.

\section{Role učitele chemie}

Role učitele chemie je klíčová jak pro účast a výsledky v ChO, tak i při volbě studijního oboru na vysoké škole. Počty účastníků z jednotlivých středních škol, kteří se probojují do Národních kol, lze chápat jako měřítko podpory ChO na těchto školách. Žáci mnoha škol se Národního kola neúčastnili ani jednou, naproti tomu jsou některá gymnázia každoročně zastoupena i několika účastníky. To je výsledkem práce konkrétních nadšených učitelů, kteří žáky vedou $\mathrm{k}$ účasti $\mathrm{v}$ soutěži, vzniká komunita řešitelů $\mathrm{ChO}$ a škola dosahuje nadprůměrně dobrých výsledků.

Klíčová role učitelů chemie na základních i středních školách vyplynula i z výsledků výzkumného šetření Faktory volby vysoké školy u zájemců o studium chemie - porovnání $s$ ostatními uchazeči. Většina uchazečů souhlasí s tvrzením, že zájem o studium chemie na vysoké škole u nich vznikl v souvislosti s osobností učitele na ZŠ (54,1 \%), osobností učitele na SŠ $(78,6 \%)$ a kvalitou výuky chemie na SŠ $(78,6 \%)$. Uvědomíme-li si, že i kvalita výuky souvisí s osobností vyučujícího, je role učitelů pro další směřování žáků a studentů zásadní.

\section{Shrnutí}

Chemickou olympiádu nelze chápat jako pouhou predmětovou soutěž, jejímž cílem jsou výsledkové listiny a vítězové. ChO je vzdělávací a motivační nástroj, který pomáhá žáky základních a studenty středních škol orientovat na studium prŕrodních věd. Pro jejich nasměrování a rozvoj je klíčová role vyučujícího chemie. Všestranná podpora učitelů chemie je tedy nezbytnou podmínkou pro zvýšení zájmu o př́rodovědné obory mezi žáky všech typů škol.

\section{LITERATURA}

1. Organizační řád Chemické olympiády, č.j.: MŠMT 14 897/2012-51, ze dne 16. 4. 2012.

\section{JAK UČIT CHEMII, ABY ŽÁKA „DOSTALA“ NA CELÝ ŽIVOT}

\section{KvĚToslava StejSkalová}

\author{
Ústav fyzikální chemie J. Heyrovského AV ČR, v.v.i., Praha \\ www.3nastroje.cz
}

Jsme jedním z padesátky pracovišt' Akademie věd ČR, které se systematicky a intenzivně vedle vědy a výzkumu více než 15 let věnuje vzdělávání zájemců o prŕírodní vědy. To znamená, že naše programy probíhají několikrát týdně a jsou zacíleny na širokou skupinu zájemců, počínaje předškoláky MŠ, přes žáky ZŠS, studenty SS̆ a VŠ až po širokou veřejnost. Přidanou hodnotou našich aktivit je, že programy na sebe navazují, a tak když pedagog se svými žáky jednou přijede, má možnost navazovat dalšími programy a u zájemců stále rozvíjet jejich schopnosti a dovednosti.

Na jaké programy se $\mathrm{k}$ nám vlastně chodí? Program pro předškoláky je pojatý jako chemické divadlo a za necelou hodinu dětem představí, kdo je vědec, ale formou pokusů ozřejmí i podstavu některých reakcí, jež nás obklopují. Barvičky se obecně osvědčily, takže reakce kyselin a zásad s antokyanovým indikátorem, to je to pravé. Pod- 
statu vzniku elektřiny $\mathrm{v}$ bateriích ukazujeme na pokusech $\mathrm{s}$ tvorbou článků $\mathrm{z}$ kovi̊ a ovoce. Na program pro předškoláky navazuje obdobný program pro žáky 1. stupně ZŠ, který bývá doplněn již interaktivním workshopem, kdy si žáci určité dovednosti vyzkouší po zhlédnutí divadla v laboratoři s pomůckami. Od páté tř́ídy již program zahrnuje téměř desítku různých workshopů objasňujících řadu zákonitostí v chemii či fyzice a interaktivita $\mathrm{v}$ experimentování posune žáky tvořící ve dvojicích o kus dál. Již tam se často objeví skuteční zájemci o přírodovědné obory, kteří svůj zájem rozvíjí mimo výuku v různých kroužcích či kurzech ve škole či jiných institucích. I u nás pořádáme např. sobotní kurzy či kroužky pro zájemce o chemii. Ročně takto pracujeme asi s 50 dětmi, kdy žák u nás stráví přibližně 20-25 hodin za celý rok a projde experimentováním v EDU laboratoři desítku různých témat pod dohlednem lektorů, což jsou naši SŠ a VŠ stážisté.

Spolupráce se středními školami je rovněž dlouholetá a intenzivní. S některými školami dokonce řešíme společně různé vzdělávací projekty. Základními programy jsou přednášky, exkurze, workshopy a ukázky praktických měření v laboratoři. Zájemci, kteří se často po návštěvě takového klasického programu u nás „najdou“, ve vybrané laboratoři pak absolvují svou roční či dlouhodobější stáž, kterou obhajují v různých soutěžích, např. SOČ, Amavet, a často ve spolupráci navazují potom i jako vysokoškoláci. Některé stáže realizujeme v projektu Otevřená věda AV ČR a od roku 2005, kdy jsme se stážemi začali, tímto systémem prošly více než 2 stovky zájemců. Práci s tzv. talentovanými studenty, to jsou ti, co mají nejen talent, ale i neutuchající zvídavost, píli a vytrvalost, vykonáváme i vdalších našich projektech, kde $\mathrm{s}$ podporou grantů (MŠMT - program podpory nadaných žáků ZŠ a SS̆) pak můžeme realizovat i prázdninové letní školy či dalši kurzy (NANO2021, ${ }_{8}$ Kyslík v ${ }_{5}$ Boru, ${ }_{4}$ Berrylium ${ }^{2}$ aj.).

Z popsaných aktivit je zřejmé, že naše akce jsou akcemi prezenčními. Jak to tedy bylo $\mathrm{v}$ době covidové uzávěry škol? Zpočátku to bylo smutné! Kromě natáčení výukových videí takříkajíc do zásoby jsme nemohli dělat nic. Když se situace trochu zlepšila, zahájili jsme komorní programy pro jednotky žáků (do 10) čili kroužky / sobotní kurzy, a nakonec jsme v rámci programu AV ČR s titulem „Pozvěte si vědce do výuky“ odučili přes počítač více než 50 hodinových přednášek představujících chemii v třicítce škol po celé České republice. Někteří pedagogové, se kterými jsme tak navázali novou spolupráci, si již ted', kdy opět probíhá prezenční výuka, s námi čile domlouvají návštěvu programů v ústavu či nás ve škole.

Zmínila jsem pedagogy - ano, to jsou ti, co se s námi potkávají a navazují spolupráci. Osobní kontakt je nezastupitelný. Na konferenci 4EDU v Litvínově jsem potkala řadu nových pedagogů, a tak očekávám nové spolupráce a $\mathrm{z}$ nich nové zájemce o přírodní vědy, které chemie třeba „dostane“ na celý život.

\section{GYMNÁZIUM JOSEFA JUNGMANNA ONLINE ANEB KDYŽ SE CHCE, VŠECHNO JDE}

\section{RADKA BaLOUNOVÁ}

\author{
Gymnázium Josefa Jungmanna, Litoměřrice \\ $w w w . g j j . c z$
}

\section{GJJ se představuje}

Gymnázium Josefa Jungmanna je školou, která respektuje tradici a je otevřená novým trendům a výukovým metodám. Jsme školou, která se chová vstřícně a partnersky k rodičům a kde jsou dobré vztahy mezi učiteli a žáky i mezi všemi navzájem. Vizí naší školy je náročnost a laskavost. Gymnázium Josefa Jungmanna je čtyřleté a osmileté gymnázium. Jsme fakultní školou Př́rodovědecké fakulty Univerzity Jana Evangelisty Purkyně a fakultní školou Filosofické fakulty Univerzity Jana Evangelisty Purkyně. Gymnázium Josefa Jungmanna se profiluje jako škola s tradičním posláním přípravy žáků na vysoké školy, jako škola, kde jsou sdílené hodnoty definované učiteli a žáky, a jako škola, která je otevrenená novým trendům a výukovým metodám.

\section{Co se nám dařilo v online výuce}

Gymnázium Josefa Jungmanna přešlo na online výuku 16. března $2020 \mathrm{v}$ prostředí MS Teams a výuka všech předmětů probíhala podle rozvrhu. U každého předmětu byla rozdělena na synchronní (kdy probíhal výklad nebo skupinová práce za aktivní účasti pedagoga) a asynchronní část (kdy byla žákům zadána práce, na které mohli pracovat sami, a vyučující byl v pozici konzultanta). Distanční výuka byla doplňována online besedami se zajímavými osobnostmi např́č předměty. Studenti měli možnost se účastnit virtuálních prohlídek muzeí, galerií apod. Konkrétně se jednalo o Památník Terezín a Národní galerii. Studenti mohli navštívit virtuálně výstavy s odborným komentářem $\mathrm{v}$ době, kdy nebylo možné vyjet na exkurze. Současně se uskutečnily např́iklad Pátky s vědou (ve spolupráci s Nadací ORLEN Unipetrol) - nahrávání přednášek osobností z oblasti vědy a jejich prezentace na YouTube. Byli jsme rádi, že k nahrávání přednášek došlo i v době covidové a nepřerušila se tato tradice. Přednášky byly realizovány bez přítomnosti studentů, kteří si je poté mohli zhlédnout v prostředí distanční výuky a prodiskutovat témata společně se svými pedagogy. Další akcí s dlouhou tradicí je Gaudeamus na GJJ - online setkání s našimi absolventy, kteři představovali své fakulty a mluvili o studiu, přijímacích zkouškách a životu na vysokých školách. Netradiční byla také výuka předmětu Přrírodovědná praktika, která zahrnuje praktickou výuku fyziky, chemie a biologie. Praktická výuka byla přenesena do domácího prostředí a byla koordinována pedagogy. Studenti natáčeli chemické a fyzikální pokusy, přijímali ekologické výzvy a výuka byla orientována do oblasti bádání a samostatné 
práce. A jak to probíhalo konkrétně? Studenti se seznámili s postupem chemického pokusu, který obdrželi přes MS Teams. Poté zhlédli video a do protokolu zpracovali výsledky. Nebo dostali návod s pracovním postupem ${ }^{1}$ a museli natočit své video, sestříhat, udělat fotografie a zodpovědět kontrolní otázky. Pedagogové dále využívali počítačové simulace např. při výuce názvosloví organických sloučenin ${ }^{2}$ nebo studentům zprostředkovali výklad prostřednictvím grafických tabletů při psaní vzorců. $\mathrm{V}$ rámci ekologické výzvy se studenti zaměřili na domácí recyklaci odpadu z papíru. Přes MS Teams obdrželi návod jak na to a potom již pracovali v domácím prostředí. Své výtvory museli nafotit a poslat. Zajímavá byla také úloha na koloběh vody v sáčku, kdy se mohli sami přesvědčit, jak se voda vypařuje, vznikají mraky a jak prší. Voda v sáčku se díky slunečnímu záření zahřivá, odpařuje, pára nemá kam unikat, a tak zkondenzuje a můžeme pozorovat „déšt‘“. Domácí pokusy vedly studenty $\mathrm{k}$ samostatnosti a zlepšení ICT gramotnosti. Na jednoduchých pokusech si studenti bez pedagoga mohli sami vyzkoušet principy základních chemických dějů a díky zapáleným pedagogům to šlo i v distanční výuce.

\section{LITERATURA}

1. https://www.avcr.cz/cs/pro-verejnost/veda-na-doma/ pokusy/, staženo 15. 12. 2021.

2. https://molview.org, staženo 15. 12. 2021.

\section{BEZPEČNÉ CHOVÁNÍ V KYBER- PROSTORU}

\section{TOMÁŠ DAŇHELKA}

\section{Policie $\check{C}$ R, Praha \\ Tomas.Danhelka@pcr.cz}

Poslední dva roky byly náročné pro nás všechny, školství však bylo zasaženo více než jiné obory. Na téměr̆ rok a půl jsme zavřeli žáky doma. Učitelé a žáci byli postaveni před nové výzvy v podobě online vzdělávání. Za pochodu se z žáků i učitelů museli stát zkušení uživatelé výpočetní techniky a sociálních sítí. Žáci byli nuceni trávit v kyberprostoru větší část svého dne, kdy dopoledne se zde učili a odpoledne $\mathrm{v}$ jejich volném čase to byl někdy jediný způsob, jak trávit čas se svými spolužáky a kamarády alespoň na dálku.

Kyberprostor je však nebezpečný svět. Počet trestných činů páchaných v kyberprostoru nebo $\mathrm{v}$ online prostředí každým rokem přibývá (obr. 1), na rozdíl od ostatních druhů kriminality. Kybernetická kriminalita je definována v Policii ČR jako „trestná činnost, která je páchána v prostředí informačních a komunikačních technologií, včetně počítačových sítí1 “. Kybernetická kriminalita, nebo jinak řečeno kyberkriminalita, tvoří širokou škálu druhů trestné činnosti, od násilných trestných činů, jako je např́klad vydírání, přes různá podvodná jednání, mravnostní trestné činy až po trestné činy proti důvěrnosti, integritě a dostupnosti počítačových dat a systémů, pod kterými si lze představit hacking.

Nejčastějším druhem kyberkriminality, se kterou se policie setkává, jsou různá podvodná jednání, od prostých falešných inzerátů na inzertních portálech, až po sofistikované phishingové útoky, které spočívají například ve vylákání přihlašovacích údajů $\mathrm{k}$ internetovému bankovnictví poškozených prostřednictvím podvržených falešných e-mailů tvářících se, že se jedná o korespondenci od ban$\mathrm{ky}$, a falešných prrihlašovacích stránek $\mathrm{k}$ internetovému bankovnictví. Druhým nejčastějším druhem jsou různé formy hackingu, od napadení e-mailové schránky či účtu na sociální síti až po např́klad ransomware útok, kdy dojde k nabourání se do firemní sítě, jejímu zašifrování a následnému vydírání pachatelem, kdy požaduje za dešifrování výkupné zaplacené $\mathrm{v}$ téměř nevystopovatelné kryptoměně. Na třetím místě se pak následně drží trestné činy proti mravnosti, jako je šíření dětské pornografie či ještě nebezpečnější jednání sexuálních predátorů, jako je navazování nedovolených kontaktů s dítětem nebo sexuální nátlak.

Podle výzkumů prováděných mezi dětmi a mladistvými nejsou však děti jen pouhé oběti, ale i pachatelé ${ }^{2}$. Mladiství pachatelé se nejčastěji dopouštějí mravnostních trestních činů. Trendem v posledních několika letech je, že se mladiství začínají dopouštět i sexuálního násilí ve formě sexuálního nátlaku, kdy dochází $\mathrm{k}$ vydírání zveřejněním již zaslané intimní fotografie s cílem vylákat další tento intimní materiál.

Pohybu v kyberprostoru se nikdo, ani děti, již nevyhneme. Proto je nutné v rámci výuky všech předmětů, kde se pracuje s výpočetní technikou, nejen při výuce informatiky, děti učit bezpečnému chování v kyberprostoru, jako je tvorba silných hesel, důsledná kontrola informací, užívání legálního softwaru a kvalitních antivirových programů. Žáci by měli znát a měly by jim být opakovaně vštěpovány zásady netikety ${ }^{3}$, což jsou pravidla slušného chování v prostředí internetu. Žáci by si měli uvědomovat, že data, která odešlou do internetu, může někdo zneužít. Nemají nikdy úplnou jistotu, s kým skutečně komunikují a že druhá strana získané informace nezneužije. Jednou zaslaná fotografie už nejde vzít nikdy zpět.

Pokud se kdokoliv setká s podezřelým chováním na internetu, které by mohlo být trestným činem či jiným protiprávním jednáním, je nutné toto co nejdřive oznámit Policii ČR. Je nutné si zadokumentovat všechny stopy, např́klad uložením komunikace, nafocením podvodné stránky apod. Je lepší na nic nečekat a oznámit pouhé podezření, protože se stopy v kyberprostoru rychle ztrácejí a poškozených může být během krátké doby velké množství.

Naštěstí však ve školách i na internetu funguje množství šikovných osob a projektů, které se věnují osvětě a učí děti i dospělé zásadám bezpečného chování v kyberprostoru. Policie dlouhodobě spolupracuje s Asociací krajů ČR, která je autorem projektu Kraje pro bezpečný internet ${ }^{4}$. Tento projekt nabízí online kurzy pro všechny věkové kategorie i zpracované metodiky pro uči- 




Obr. 1. Kybernetická kriminalita v letech 2011 až 2020

tele. Od roku 2020 spolupracuje Policie ČR také s ČSOB na projektu Tvoje cesta \#onlinem ${ }^{5}$. Policie ČR má rovněž při každém krajském ředitelství zrrízena oddělení tisku a prevence, která mohou školy kontaktovat a blíže se informovat na možnosti spolupráce. Jako další je nezbytné zmínit projekt E-bezpečí ${ }^{6}$, realizovaný Pedagogickou fakultou Univerzity Palackého ve spolupráci s dalšími organizacemi. Věnuje se prevenci, vzdělávání i výzkumu a patří dlouhodobě $\mathrm{k}$ oceňovaným projektům $\mathrm{i} \mathrm{v}$ rámci Evropy. V neposlední řadě stojí za zmínku projekt Internetem bezpečně nabízející kromě přednášek i volně stažitelné učebnice a příručky pro výuku informatiky a bezpečného chování na internetu. Výčet není v žádném prŕípadě kompletní, při hledání na internetu lze dohledat množství dalších zdařilých projektů.

Tématům bezpečného chování v kyberprostoru je dáván ve veřejném prostoru stále větší prostor. Můžeme doufat, že to časem přinese své výsledky a množství útoků kyberkriminality začne s hlubší informovaností široké veřejnosti zase pomalu klesat.

\section{LITERATURA}

1. https://www.policie.cz/clanek/kyberkriminalita.aspx, staženo 15. 12. 2021.

2. https://e-bezpeci.cz/index.php/ke-stazeni/vyzkumnezpravy/117-ceske-deti-v-kybersvete/file srov. https:// www.kpbi.cz/prilohy/157_vyzkum_final.pdf, staženo 15. 12. 2021.

3. https://www.e-bezpeci.cz/index.php/rizikove-jevyspojene-s-online-komunikaci/dalsi-temata/2226netiketa-pravidla-slusneho-chovani-uzivateluinternetu-journal, staženo 15. 12. 2021.

4. www.kpbi.cz, staženo 15. 12. 2021.

5. https://www.csob.cz/portal/csob/spolecenskaodpovednost/odpovedne-podnikani/pro-vzdelani/tvoje -cesta, staženo 15. 12. 2021.

6. www.e-bezpeci.cz, staženo 15. 12. 2021.

7. www.internetembezpecne.cz, staženo 15. 12. 2021.

\section{VÝHODY VÝUKY NA YOUTUBE}

\section{Olga RyParová}

autorka projektu Olinium
olga.ryparova@gmail.com

Během pandemie jsme ze dne na den museli přejít na online výuku. Mou výhodou bylo, že jsem již pár měsíců před lockdownem založila YouTube kanál Olinium, kam jsem nahrávala výuková videa o chemii. Prakticky během pár hodin po uzavření škol jsem se rozhodla, že začnu po práci vysílat hodinové lekce chemie pro všechny studenty, kteři projeví zájem. První rok jsem učila 5krát týdně, během druhého pandemického roku 3 krát týdně. $V$ př́spěvku najdete dopady, které zpětně hodnotím po dvou letech výuky chemie na YouTube.

\section{Proč učit na YouTube}

Učit online nebo připravovat videa dopředu a pak je studentům poslat. To je něco, co jsme skoro všichni učitelé nebo lektoři zažili během pandemie. Vysílali jsme videokonference přes Zoom, Microsoft Teams nebo Google Classroom. Proč jsem však postupně přešla na YouTube?

YouTube je jedna z největších sociálních sítí zaměřených na video. Většina studentů na nich sleduje zábavní i vzdělávací obsah. Jsou na konzumaci obsahu tímto způsobem navyklí a také mají na youtubové platformě své vzory. Takže se k YouTube pravidelně vrací.

Oproti videokonferenčnímu softwaru má YouTube velkou výhodu. At' už si nahrajete video dopředu doma, nebo ho vysíláte živě, video si uložíte automaticky v cloudu, který je zdarma. Za ty dva roky bych potřebovala zhruba úložiště 1 TB, což není levná záležitost. Když už jednou obsah vytvoříte, můžete ho recyklovat pro studenty, kteří onemocní a potřebují dohnat látku ze školy. Můžete jim tak usnadnit rychlý návrat do školy, když jim zašlete 
probranou látku ve videu. Každé video má svůj unikátní odkaz a studentovi stačí mít internetové připojení, aby se $z$ videa naučil zmeškanou chemii.

Další výhodou je možnost si rozdělit video na kapitoly, takže studenti jsou schopní ve videu jednoduše přeskočit k látce, kterou potřebují, aniž by museli složitě projíždět celý záznam.

Díky jednoduchému propojení můžete na pár kliků vložit do videa odkaz třeba na pokus $\mathrm{z}$ jiného chemického kanálu nebo video, které jde do hloubky učiva pro zájemce. Tím můžete studentům, kteří chtějí chemii dále studovat, prohloubit znalosti, které už přesahují středoškolské učebnice.

\section{Začít s výukou můžete hned}

Pokud jste o výuce na YouTube uvažovali, nepotřebujete žádné drahé vybavení a ani výjimečné schopnosti. Nejsnadnější způsob je nahrávat zvuk a kreslit u toho na bílé pozadí nebo do prezentace. $\mathrm{K}$ tomu stačí notebook a grafický tablet, na který kreslíte poznámky. Microsoft Windows má zdarma $\mathrm{v}$ počítači program Ink.

Druhý typ videí mám takový, že sedím před kamerou a vysvětluji opět kreslením různá chemická témata. Do těchto videí jde pěkně vkládat obrázky, takže už to vyžaduje postprodukční úpravu. $\mathrm{V}$ případě, že byste potřebovali poradit $s$ nastavením streamu, natáčením nebo čímkoliv jiným, ozvěte se mi na mých sociálních sítích.

\section{Vzájemná komunikace jen přes chat}

Všechny večerní hodiny chemie jsem vysílala živě, interakce se studenty probíhala přes chat a po skončení streamu jsem video upravila a uložila př́mo na YouTube. Jediná věc, která schází oproti klasickým videokonferenčním hovorům, je nemožnost studentů připojit se s videem/ audiem. Komunikace $\mathrm{s}$ nimi probíhala jen přes chat. I to ale u mnoha introvertních studentů napomohlo tomu, že se nebáli zeptat písemně, zatímco v klasické hodině by se báli prred trrídou promluvit.

\section{Jak hodnotím dva roky své výuky?}

Můžu zodpovědně říct, že má práce, kterou jsem do tvorby veřejné výuky dala, se vyplatila. Dostala jsem už stovky poděkování za úspěšně složené maturitní nebo příjímací zkoušky z chemie. Nejvíce mne ovšem překvapilo, že jsem ovlivnila desítky studentů v tom, že vůbec šli studovat chemii na vysokou školu. At' už se rozhodnete ukládat videa veřejně nebo soukromě pouze pro své studenty, do budoucna se k videím můžete vrátit a stále je používat.

Pandemie byla extrémní situace a ne všichni učitelé se s ní stihli poprat. Zpětně hodnotím jako největší př́ínos toho takto veřejně učit to, že si studenti mohli zcela svobodně vybrat, aby se se mnou pravidelně učili chemii. Pokud jim nevyhovovalo něco konkrétního, napsali mi zpětnou vazbu. Díky tomu jsem se dokázala ve výuce posunovat.

Komu můj styl nevyhovoval vůbec, našel si jiný zdroj. Před dvěma lety bych nevěřila, že by se mohly najít tisíce lidí z Česka i Slovenska, kteří se mnou budou zcela dobrovolně trávit hodinu každý den.

- Čukatová R., Herink T., Holzhauser P., Stejskalová K., Balounová R., Daňhelka T., Ryparová O.: Chem. Listy 116, 73-79 (2022).

- https://doi.org/10.54779/chl20220073 